medRxiv preprint doi: https://doi.org/10.1101/2020.06.20.20134205; this version posted June 22, 2020. The copyright holder for this preprint (which was not certified by peer review) is the author/funder, who has granted medRxiv a license to display the preprint in perpetuity. It is made available under a CC-BY 4.0 International license .

\title{
Mapping infectious disease mortality onto the within-host dynamics of pathogen growth
}

Tim O'Sullivan, Kristofer Wollein Waldetoft \& Sam P. Brown

\section{Abstract}

Infectious diseases remain a major cause of global mortality, yet basic questions concerning the relationship between within-host processes governing pathogen burden (pathogen replication, immune responses) and epidemiological patterns of mortality remain obscure. In standard epidemiological models of bacterial and viral infections ('compartmental models'), pathogen-induced mortality is described as a constant risk factor, unchanging with time since infection or the dynamics of the pathogen population inside the host. Here we review experimental data illustrating the failure of this assumption, with multiple infection models highlighting an accelerating risk of death with time since infection. Next, we show that the dynamics of infection-mediated death are phenomenologically similar to the dynamics of all-causes death, captured by an exponentially increasing instantaneous mortality or 'hazard' (a Gompertz function). We then sketch a series of within-host pathogen models and highlight that multiple models are consistent with existing Gompertz-like infection mortality data, including: (1) exponential pathogen growth and a linear mapping between pathogen density and host hazard, and (2) linear pathogen growth and an exponential mapping between pathogen density and host hazard. We review critical experimental questions that our work highlights, requiring additional non-invasive data on pathogen burden throughout the course of infection, and end with a discussion on the unpicking of the mechanistic and dynamical basis of accelerating mortality risk during the course of human infections. 
medRxiv preprint doi: https://doi.org/10.1101/2020.06.20.20134205; this version posted June 22, 2020. The copyright holder for this preprint (which was not certified by peer review) is the author/funder, who has granted medRxiv a license to display the preprint in perpetuity. It is made available under a CC-BY 4.0 International license.

\section{Introduction}

Infectious disease research operates across multiple scales, from cell biologists studying the molecular interactions between pathogen and host cells, through to epidemiologists studying the trajectories of infection case counts through populations of hosts. The breadth of infection research is a testament to the enduring importance of infections to humanity and provides an incredible resource to infection researchers working across these scales. Yet the specialization of research has led to a relative disconnect between the within-host focus of biomedical research and the among-host focus of epidemiological research. In particular, we focus in this study on a disconnect over the analysis of a key infection outcome - life or death.

On an epidemiological scale, the standard model framework for bacterial and viral ('microparasite') infections is known as 'compartmental' models, which structure host populations into compartments of 'susceptible' (S) and 'infected' (I) classes [1]. Under these models, individuals in the S class can transition into the I class (following contact with an I individual), and then exit the I class following pathogen clearance or death (Figure 1A). A key simplification in these models is that the mortality rate of an individual jumps from a baseline rate $\mu$ (while uninfected) to $\mu+\alpha$ while infected ( $\alpha$ capturing the additional pathogen-induced mortality), and returning immediately to $\mu$ when and if the infection is cleared (Figure 1B). A consequence of this modeling approach is that probability of survival will follow an exponential decay through time since infection (Figure 1C), reflecting the constant and elevated risk posed by infection. This constant mortality assumption has been flagged before as problematic [2-4] and is commonly relaxed in epidemiological models with very heterogeneous infection burdens, such as macroparasitic worm infections $[5,6]$. Here we focus on microparasite infections and ask first what are the empirical patterns of mortality following experimentally induced infections, and then develop statistical and mathematical models of dynamical mortality in light of these data. 
medRxiv preprint doi: https://doi.org/10.1101/2020.06.20.20134205; this version posted June 22, 2020. The copyright holder for this preprint (which was not certified by peer review) is the author/funder, who has granted medRxiv a license to display the preprint in perpetuity.

It is made available under a CC-BY 4.0 International license.
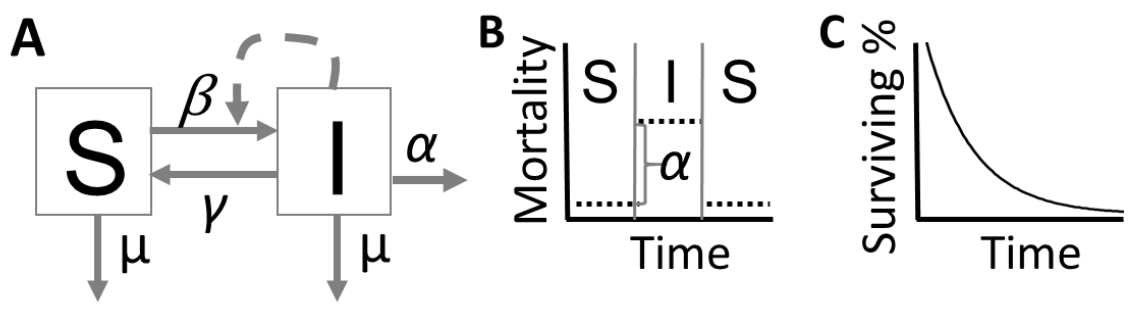

Figure 1. A schematic summary of mortality assumptions in a compartmental SIS epidemiological model. (A) An SIS compartmental model. Individuals are allocated to either the S or I class, dependent on whether susceptible or infected. Transitions among states are governed by coefficients capturing transmission $(\beta)$, recovery $(\mathrm{Y})$ and mortality $(\alpha)$. (B) The transitions between $S$ and I states in model (a) imply instantaneous switches in mortality, between a background rate $\mu$ and an enhanced rate $\mu+\alpha$. (C) The constant (and elevated) rate of instantaneous mortality during infection implies that among the infected class, survivors (in the absence of subsequent infections or recoveries) will decay exponentially with time since infection.

\section{Results}

To assess the validity of standard epidemiological assumptions (Figure 1), we gathered data that represent a phylogenetically diverse range of microparasites and metazoan hosts [7-10], including a fruit fly / Listeria monocytogenes, mouse / Trypanosoma brucei , waxmoth / Pseduomonas aeruginosa, and nematode / Staphylococcus aureus models. These infection models represent many different mechanisms of host immunity and pathogen virulence, and thus capture a large diversity of parasite-host interactions. Each dot in Figure 2 illustrates the proportion of surviving individuals at time $t$ since experimental infection. In these experiments, age-controlled cohorts were infected at defined times and with a defined pathogen dose or exposure. In the fruit fly and waxmoth models, hosts were infected with a known number of colony forming units (CFU) of the bacterial pathogen. For the mouse model, hosts were infected with a known number of parasites, cultured from immunosuppressed mouse hosts. Nematodes were infected with a typical slow killing assay [11], which involved a discrete exposure time of feeding on the bacterial pathogen (i.e. in C. elegans and allied bacterivorus species, infections are the results of post-feeding colonization, not injection).

Using the entire survival data, we next fitted an exponential model for each system (red lines, Figure 2). This corresponds to a constant mortality rate for each host-parasite combination, as is assumed in the epidemiological compartmental modeling approach discussed above (Figure 1). On even a cursory 
medRxiv preprint doi: https://doi.org/10.1101/2020.06.20.20134205; this version posted June 22, 2020. The copyright holder for this preprint (which was not certified by peer review) is the author/funder, who has granted medRxiv a license to display the preprint in perpetuity.

It is made available under a CC-BY 4.0 International license .

examination, the data are not consistent with an exponential decline in survivorship. All the survivorship curves systematically deviate from the best fit exponential with higher survivorship early in the infection, and lower survivorship late in the infection. In other words, the data support an increasing risk of death as the infection proceeds.

\section{$\underline{\text { Pathogen-induced death as a process of accelerated aging }}$}

This pattern of increasing instantaneous mortality or 'hazard' through time is familiar from the aging literature.

In a human context, the instantaneous risk of death increases approximately exponentially, doubling approximately every 7 years [12]. In controlled animal aging experiments, the same statistical patterns are observed, with the absolute rates varying with the animal [13-15], their genetics [16], and the environment $[17,18]$. Inspired by this connection, we decided to test one of the most common models from the aging literature, the Gompertz [19]. Briefly, the two parameter Gompertz mortality function is defined by:

$$
m(t)=b * e^{a * t} \quad \quad \text { [Equation 1] }
$$

When $a=0$, the Gompertz recovers the exponential distribution with a constant mortality rate $b$. Increasing $a$ leads to an increasing acceleration of instantaneous mortality with time [20,21]. We used a nonlinear least squares method [22] in the statistical software $R$ [23] to fit these distributions to the experimental data, and observe that models of accelerated mortality (akin to aging) fit the survival data better than the exponential model (Figure 2), but at the expense of an additional parameter. To assess model fit while accounting for parameter number, we used an information criterion approach, as presented in Table 1. The results clearly show the extra parameter in the Gompertz model is well justified, supporting the conclusion that in these diverse models, the risk of death is accelerating following the initiation of infection - analogous to the acceleration in mortality across entire lifespans, known as aging. 
medRxiv preprint doi: https://doi.org/10.1101/2020.06.20.20134205; this version posted June 22, 2020. The copyright holder for this preprint (which was not certified by peer review) is the author/funder, who has granted medRxiv a license to display the preprint in perpetuity.

It is made available under a CC-BY 4.0 International license.
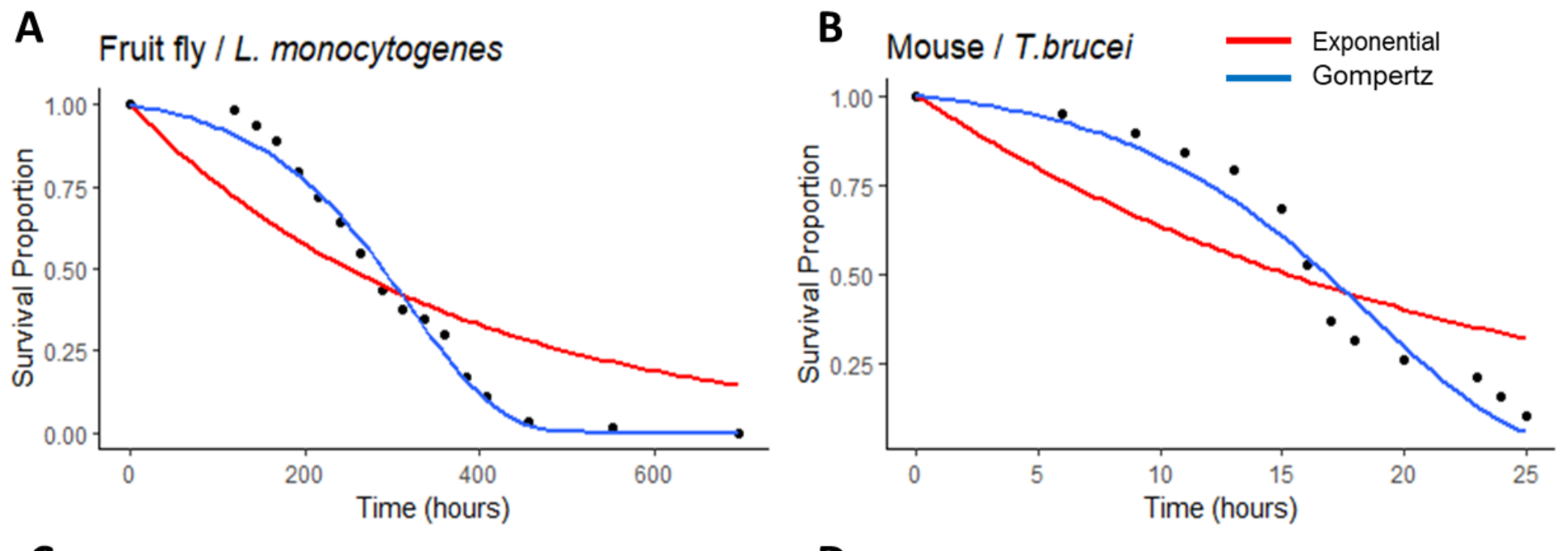

\section{Waxmoth / P. aeruginosa}
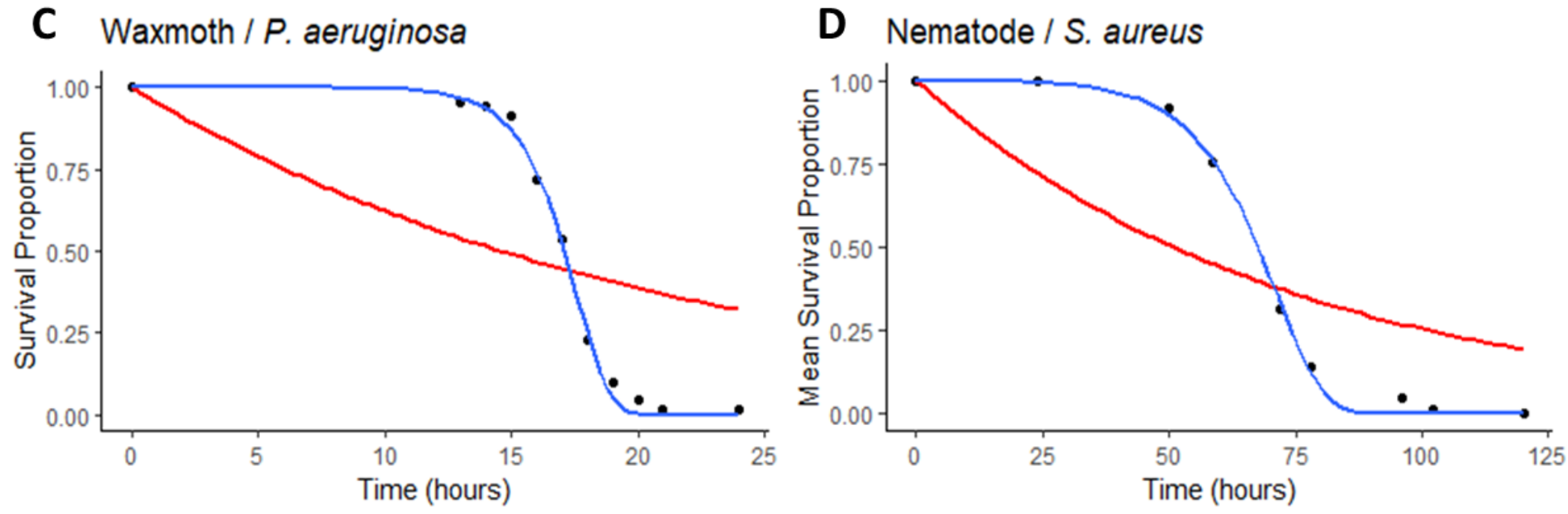

Figure 2. Survival data for four host-microparasite model systems indicate the failure of the constant mortality assumption. Black dots represent experimental data from (A) a fruit fly/ Listeria model ( $N=64,[7])$, (B) a mouse/trypanosome model ( $\mathrm{N}=19,[8])$, (C) a waxmoth/P. aeruginosa model ( $\mathrm{N}=71$, [9]), and (D) a nematode/ $S$. aureus model $(\mathrm{N}=120,[10])$. The red lines represent exponential model fits (constant mortality rate), the blue lines represent a Gompertz model fit, which allows for accelerating mortality in time. Model fits were made using a nonlinear least squares method in $\mathrm{R}$ [22]. Parameter estimates and model comparisons are in Table 1.

\section{Table 1. Comparison of exponential and Gompertz model fits.}

\section{Data}

Fruit fly / L.moncytogenes [7]

Mouse / T. brucei [8]

Waxmoth / $P$. aeruginosa [9]

Nematode / S. aureus [10]
Model

Exponential

Gompertz

Exponential

Gompertz

Exponential
Gompertz

Exponential

Gompertz
AIC

$-7.21532$

$-56.16302$

$-5.217522$

$-27.34543$

9.718088

$-42.53678$

4.020253

$-39.09753$
Fitted Parameters

$\lambda=0.002778485$

$b=0.0004192727, a=0.0098624234$

$\lambda=0.045424$

$b=0.007434867, a=0.166813158$

$\lambda=0.047421$

$b=1.150947 \mathrm{e}-06, \quad a=0.7620354$

$\lambda=0.013633$

$b=6.250612 \mathrm{e}-05, \quad a=0.1044699$ 
medRxiv preprint doi: https://doi.org/10.1101/2020.06.20.20134205; this version posted June 22, 2020. The copyright holder for this preprint (which was not certified by peer review) is the author/funder, who has granted medRxiv a license to display the preprint in perpetuity.

It is made available under a CC-BY 4.0 International license.

However, while experimental infection and aging give rise to similar patterns of survival, there is a difference in underlying process. In the case of the experimental infection models illustrated above, we have a clear and singular cause of death - the pathogen (uninfected controls showed minimal mortality across the timescale of observation, specifically, survivorship in control (uninfected) cohorts at the final time point ranged from $~ 80 \%$ (waxmoth) to $100 \%$ (nematodes) [7-10]. This causal clarity offers a window into the study of mortality, as we have a potential internal currency (pathogen dynamics) to map onto the changing risk of death.

\section{Pathogen-driven models of accelerating mortality}

The observation of an approximately exponential increase in risk (i.e., a Gompertz function) suggests one simple mechanistic model: the instantaneous mortality is linearly proportional to the instantaneous burden of an exponentially expanding pathogen population. We can break this down into two sets of assumptions. First, we assume that within-host pathogen density $p(t)$ is growing exponentially, $p(t)=p_{0} e^{r t}$, with dynamics governed by initial inoculum $p_{0}$ and an exponential pathogen growth rate $r$. Given an acute infection, this is a plausible assumption and commonly made in 'nested' epidemiological models [2]. Next, we assume that instantaneous mortality $m(t)$ is linearly proportional to bacterial burden, with mortality coefficient $v$, that is $m(t)=v * p(t)$. This again is a plausible assumption, capturing the notion that higher pathogen burdens are more dangerous. Putting these pieces together, we arrive at an instantaneous mortality function that is driven by pathogen demography, and is identical to the Gompertz function (given $b=v * p 0$ and $a=r$ );

$$
m(t)=v * p_{0} e^{r t} \quad \quad \text { [Equation 2] }
$$

In Figure 3, we focus on the mouse / T. brucei infection model (Kaboré, Figure 2B), and use our fitted Gompertz function (Table 1) plus independent estimates of inoculum density $\left(p_{0}=5^{*} 10^{4}\right)$ to parameterize our mechanistically explicit model in Equation 2. From this exercise, we find $r=a \sim 0.167 / h r$, and per-capita virulence $v=b / p 0 \sim 1.5 * 10-7 /($ cells $* h r)$. Plotting the implied pathogen growth through time (blue line,

Figure 3) the model therefore predicts that by 25 hours, when the majority of hosts are dead, pathogen density has reached approximately $3 * 10^{7}$, a plausible density in murine-trypanosome infection models [24,25]. While the model assumptions of exponential growth and a linear mapping appear plausible, and the resulting Gompertz equation fits the data above, we must heed the caution that multiple mechanistic processes can be 
medRxiv preprint doi: https://doi.org/10.1101/2020.06.20.20134205; this version posted June 22, 2020. The copyright holder for this preprint (which was not certified by peer review) is the author/funder, who has granted medRxiv a license to display the preprint in perpetuity.

It is made available under a CC-BY 4.0 International license .

consistent with a single statistical pattern $[26,27]$. In the following section we explore a number of scenarios that are consistent with plausible within-host processes and also generate the observed acceleration in risk during the course of infection.

Data on the within-host dynamics of infection are sadly limited, but in some studies there is little change through time in pathogen density [28], and in some cases there are even appreciable declines - albeit from deliberately high inocula [29]. In light of these data, we could conservatively assume that within-host dynamics are relatively constant, i.e., $p(t)=p_{0}$. From this standpoint, we can still return to a Gompertz mortality function by assuming $m(t)=b * e^{a * t}$, i.e., the acceleration in risk is independent of the demography of the pathogen. Figure 3B illustrates this model, again fitted to the Kaboré et al. data [8]. In this case, we can use observed $p 0$ data to constrain pathogen load, but by assumption this has no mechanistic connection to changing mortality.

In a third avenue of approach, we assume a linear expansion of the pathogen following infection at rate $g$, $\left(p(t)=p_{0}+g t\right)$. In this case, we can again return to a Gompertz function in the limit of $p 0->0$, given that mortality is an exponential function of pathogen density $m(t)=v * e^{p(t)}$. By substation, we can now connect within-host pathogen growth to population mortality by $m(t)=v * e^{g(t)}$. Applying this function to the Kong data (Figure 3C) we see that while we fit the survival data, the implied within-host behavior is not plausible in this case, implying pathogen loads that remain well below the observed $p_{0}$. Finally, in Figure $\mathrm{S} 1$ we take the same 3 models illustrated in Figure 3 for the mouse/trypanosome system and apply to the other 3 experimental model systems. While we see different implied within-host behaviors with differing plausibilities, the main take home from this analysis is that inferring within-host behavior purely from mortality trajectories is an underdetermined problem. In short, we need to look inside hosts to directly observe pathogen dynamics. 
medRxiv preprint doi: https://doi.org/10.1101/2020.06.20.20134205; this version posted June 22, 2020. The copyright holder for this preprint (which was not certified by peer review) is the author/funder, who has granted medRxiv a license to display the preprint in perpetuity.

It is made available under a CC-BY 4.0 International license .
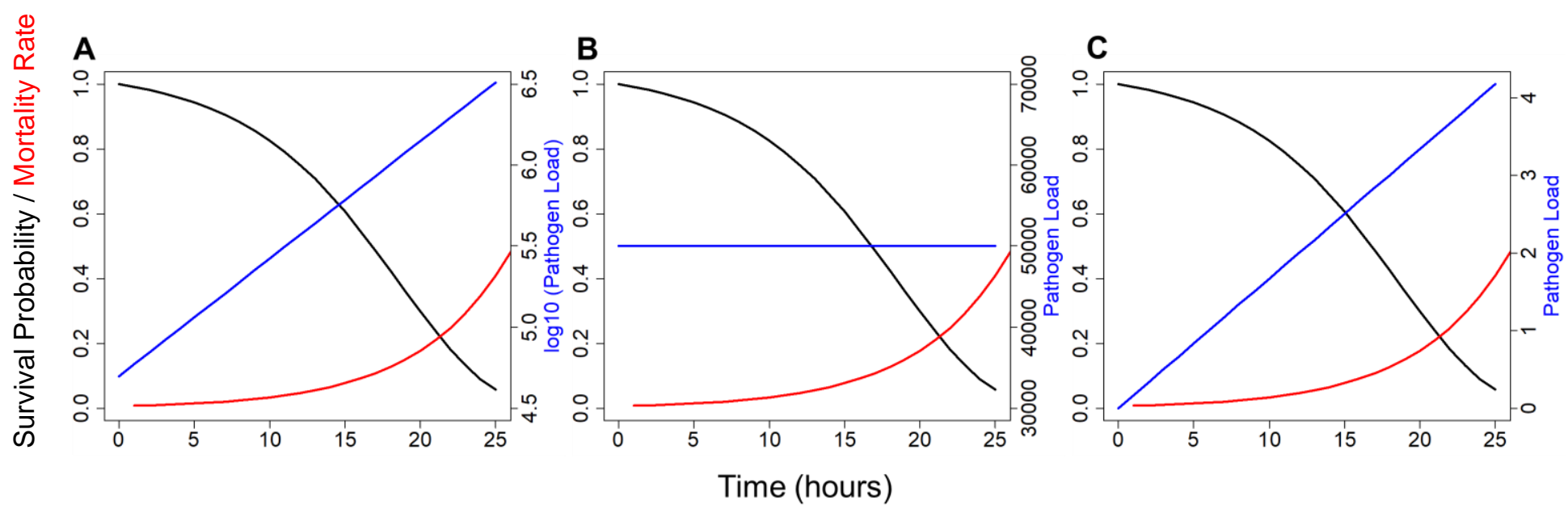

Figure 3. Three distinct within-host models that are consistent with the observed survival data for the mouse / T. brucei system. A) Exponential pathogen growth with a linear mapping from pathogen density to instantaneous mortality. B) constant pathogen load post infection, with independent and exponentially increasing mortality. C) linear pathogen growth with exponential mapping to mortality. Model fits are to the data in Figure 2a.

\section{Discussion}

In contrast to the assumptions in standard epidemiology models (Figure 1), our analysis shows that the instantaneous rate of mortality increases exponentially during the course of infection, in 4 diverse experimental models of infection (Figure 2). This exponential increase in risk is a hallmark of aging in humans [30] and other organisms [31], and is phenomenologically described by the two parameter Gompertz equation (Table 1).

Unlike the aging literature, however, we have in the case of acute lethal infections a clear causal currency -

the bacterial (Figure 1; A, C, and D) or protozoan (B) pathogen. Building on this causal connection, we next outline potential mechanistic paths between the within-host dynamics of the pathogen and the observed acceleration in mortality (Figure 3). Our analysis demonstrates that multiple causal processes are consistent with the observed survival data, illustrating that the observation of accelerating mortality alone is insufficient to infer the underlying process of mortality.

Our mechanistic analyses highlight two sets of assumptions that together combine to define instantaneous mortality, $m(t)$, in terms of pathogen dynamics $p(t)$. First, we need to define the nature of pathogen growth $p(t)$. In Figure 3 we consider exponential (Figure 3A), linear (Figure 3C) or no growth (Figure 3B). Other reasonable choices include logistic growth, or even declines from a high inoculum, as observed in some experimental models with large challenge inoculations [28]. Second, we need to define how pathogen 
medRxiv preprint doi: https://doi.org/10.1101/2020.06.20.20134205; this version posted June 22, 2020. The copyright holder for this preprint (which was not certified by peer review) is the author/funder, who has granted medRxiv a license to display the preprint in perpetuity.

It is made available under a CC-BY 4.0 International license .

dynamics $p(t)$ shape instantaneous mortality $m(t)$. In Figure 3 we consider a linear mapping (Figure 3A), exponential mapping (Figure 3C) or $m(t)$ independent of $p$ (Figure 3B). Again, other choices could be made, for instance a mapping incorporating infection history, $m(t) \sim \int p(t) d t$. For each of these sets of assumptions on the form of $p(t)$ and $m(t)$, we next review possible data sources to constrain and inform our model assumptions.

To address the challenge of measuring within-host pathogen dynamics $p(t)$, broadly two paths are available. The first and simplest path is destructive sampling, where a large cohort is tracked during the course of infection, and sample individuals are taken at intervals and sacrificed to estimate pathogen burden at time $t$, e.g. by grinding up the host or host tissue and plating on selective media for a defined bacterial pathogen [32,33]. Destructive sampling is simple in outline, but raises challenges of individual host heterogeneity (data is gathered across hosts) and the requirement for very large cohort sizes in order to gather data late in the progression of infection [34,35]. A second path is to track infection burden non-destructively via repeat measures from the same population of hosts. While requiring fewer hosts to produce workable data, the requirement to minimize invasive observational effects can become a limitation [36]. One attractive route is to use fluorescent or luminescent pathogen strains, that can be imaged within a host non-invasively [37]. This path has been taken in diverse animal models, from mice [38] to nematodes [39] , although calibration of infection burden is a concern - typically these reporter construct studies are more focused on location of infection $[28,40]$ rather than estimating burden. In the absence of light-based reporters, other routes are possible via the sampling of peripheral fluids, e.g. for malaria $[41,42]$. However the risk of observer effects are higher in these cases, as attempting to sample from moribund hosts one may inadvertently accelerate mortality, thereby warping the relationship between pathogen burden and death $[43,44]$.

Turning to the mapping function, $m(t)=f(p(t))$, some evidence can be gleaned from experiments varying inocula [45-47], but without tracking subsequent dynamics of the pathogen within the host, this approach is limited. To empirically estimate mapping functions will require empirical measures of instantaneous mortality $m(t)$ (from survival data, e.g., Figure 3), together with measures of pathogen density, $p(t)$, as outlined in the previous paragraph. In future work, we aim to pursue this agenda using an experimental $C$. elegans infection system. 
medRxiv preprint doi: https://doi.org/10.1101/2020.06.20.20134205; this version posted June 22, 2020. The copyright holder for this preprint (which was not certified by peer review) is the author/funder, who has granted medRxiv a license to display the preprint in perpetuity.

It is made available under a CC-BY 4.0 International license.

In our current work, we focused on diverse infection models, with divergent modes of pathogen replication and host immune control. Despite this biological diversity, we witnessed a similar phenomenological pattern of accelerating risk. We note however that while our results are illustrative of diverse infection systems, they do not represent a formal meta-analysis of infection data, and we aim to conduct a systematic literature review in future work.

Returning to the epidemiological focus of our introduction, what are the epidemiological implications of a failure of the constant mortality assumption in compartmental models (Figure 1)? In contrast to our study of synchronized cohorts of experimentally induced infections (Figure 2), in most natural epidemiological contexts, the onset of infections are un-synchonised, and the age of infection ( $t$ in our analyses above) is unknown. In this context, the standard SIS model framework is often reasonable, and when the model produces dynamics that are 'too fast' due to the sudden jump from $S$ to I, simple fixes are available such as through the addition of a latent or 'exposed' class in SEIR (Susceptible-Exposed-Infected-Recovered) models to delay epidemiological progress [48]. Our approach raises the potential for incorporating age of infection $(t)$ and pathogen dynamics $p(t)$ into analyses, a topic which has been pursued under the banner of 'nested' epidemiological models $[49,50]$. While previous work on nested epidemiology has relied on 'plausible' models of $p(t)$, e.g., Antia et al. 1994, Gilchrist \& Sasaki 2002 [51,52], we caution that multiple within-host processes can be consistent with epidemiological data (Figure 3). What we now require are studies to empirically determine the within-host dynamics of infection and their mapping to mortality. With this data we will be able to further constrain models and explore new avenues for intervention strategies that are conditioned on the progressive state of infectious disease. 
medRxiv preprint doi: https://doi.org/10.1101/2020.06.20.20134205; this version posted June 22, 2020. The copyright holder for this preprint (which was not certified by peer review) is the author/funder, who has granted medRxiv a license to display the preprint in perpetuity. It is made available under a CC-BY 4.0 International license.

\section{References}

1. Anderson RM, May RM. Population biology of infectious diseases: Part I. Nature. 1979;280: 361-367. doi:10.1038/280361a0

2. Mideo N, Alizon S, Day T. Linking within- and between-host dynamics in the evolutionary epidemiology of infectious diseases. Trends in Ecology and Evolution. Elsevier Current Trends; 2008. pp. 511-517. doi:10.1016/j.tree.2008.05.009

3. Gog JR, Pellis L, Wood JLN, McLean AR, Arinaminpathy N, Lloyd-Smith JO. Seven challenges in modeling pathogen dynamics within-host and across scales. Epidemics. 2015;10: 45-48. doi:10.1016/j.epidem.2014.09.009

4. Handel A, Rohani P. Crossing the scale from within-host infection dynamics to between-host transmission fitness: A discussion of current assumptions and knowledge. Philos Trans R Soc B Biol Sci. 2015;370. doi:10.1098/rstb.2014.0302

5. Pullan RL, Smith JL, Jasrasaria R, Brooker SJ. Global numbers of infection and disease burden of soil transmitted helminth infections in 2010. Parasites and Vectors. 2014;7: 37. doi:10.1186/1756-3305-7-37

6. Truscott JE, Turner HC, Farrell SH, Anderson RM. Soil-Transmitted Helminths: Mathematical Models of Transmission, the Impact of Mass Drug Administration and Transmission Elimination Criteria. Adv Parasitol. 2016;94: 133-198. doi:10.1016/bs.apar.2016.08.002

7. Louie A, Song KH, Hotson A, Thomas Tate A, Schneider DS. How Many Parameters Does It Take to Describe Disease Tolerance? PLoS Biol. 2016;14. doi:10.1371/journal.pbio.1002435

8. Kaboré J, Camara O, Koffi M, Sanou D, Ilboudo H, Sakandé H, et al. Differences in pathogenicity and virulence of Trypanosoma brucei gambiense field isolates in experimentally infected Balb/C mice. Infect Genet Evol. 2018;63: 269-276. doi:10.1016/j.meegid.2018.05.018

9. Ross-Gillespie A, Weigert M, Brown SP, Kümmerli R. Gallium-mediated siderophore quenching as an evolutionarily robust antibacterial treatment. Evol Med Public Heal. 2014;2014: 18-29. 
medRxiv preprint doi: https://doi.org/10.1101/2020.06.20.20134205; this version posted June 22, 2020. The copyright holder for this preprint (which was not certified by peer review) is the author/funder, who has granted medRxiv a license to display the preprint in perpetuity.

It is made available under a CC-BY 4.0 International license.

10. Kong C, Yehye WA, Abd Rahman N, Tan MW, Nathan S. Discovery of potential anti-infectives against Staphylococcus aureus using a Caenorhabditis elegans infection model. BMC Complement Altern Med. 2014;14: 1-17. doi:10.1186/1472-6882-14-4

11. Tan MW, Mahajan-Miklos S, Ausubel FM. Killing of Caenorhabditis elegans by Pseudomonas aeruginosa used to model mammalian bacterial pathogenesis. Proc Natl Acad Sci U S A. 1999;96: 715-720. doi:10.1073/pnas.96.2.715

12. Kochanek KD, Murphy SL, Xu J, Arias E. National Vital Statistics Reports Volume 68, Number 9 June 24, 2019 Deaths: Final Data for 2017. 2019. Available: https://www.cdc.gov/nchs/products/index.htm.

13. Economos AC. A non-Gompertzian paradigm for mortality kinetics of metazoan animals and failure kinetics of manufactured products. Age (Omaha). 1979;2: 74-76. doi:10.1007/BF02432250

14. Austad SN. Diverse aging rates in metazoans: Targets for functional genomics. Mechanisms of Ageing and Development. Elsevier; 2005. pp. 43-49. doi:10.1016/j.mad.2004.09.022

15. Boiko OG, Labas YA, Gordeeva A V. An outline of the phylogenetic history of Metazoan aging phenomenon (to the study of creating a common Metazoa aging theory). Adv Gerontol. 2011;1: 122129. doi:10.1134/S2079057011020044

16. Petralia RS, Mattson MP, Yao PJ. Aging and longevity in the simplest animals and the quest for immortality. Ageing Research Reviews. Elsevier Ireland Ltd; 2014. pp. 66-82. doi:10.1016/j.arr.2014.05.003

17. Stroustrup N, Anthony WE, Nash ZM, Gowda V, Gomez A, López-Moyado IF, et al. The temporal scaling of Caenorhabditis elegans ageing. Nature. 2016;530: 103-7. doi:10.1038/nature16550

18. Thanos PK, Hamilton J, O'Rourke JR, Napoli A, Febo M, Volkow ND, et al. Dopamine D2 gene expression interacts with environmental enrichment to impact lifespan and behavior. Oncotarget. 2016;7: 19111- 
medRxiv preprint doi: https://doi.org/10.1101/2020.06.20.20134205; this version posted June 22, 2020. The copyright holder for this preprint (which was not certified by peer review) is the author/funder, who has granted medRxiv a license to display the preprint in perpetuity. It is made available under a CC-BY 4.0 International license.

19123. doi:10.18632/oncotarget.8088

19. Gompertz B. On the Nature of the Function Expressive of the Law of Human Mortality, and on a New Mode of Determining the Value of Life Contingencies. Philos Trans R Soc London. 1825;115: 513-583. Available: https://www.medicine.mcgill.ca/epidemiology/hanley/c609/material/Gompertz-1825.pdf

20. El-Gohary A, Alshamrani A, Al-Otaibi AN. The generalized Gompertz distribution. Appl Math Model. 2013;37: 13-24. doi:10.1016/j.apm.2011.05.017

21. Missov TI, Lenart A, Nemeth L, Canudas-Romo V, Vaupel JW. The gompertz force of mortality in terms of the modal age at death. Demogr Res. 2015;32: 1031-1048. doi:10.4054/DemRes.2015.32.36

22. Wu JW, Hung WL, Tsai CH. Estimation of parameters of the Gompertz distribution using the least squares method. Appl Math Comput. 2004;158: 133-147. doi:10.1016/j.amc.2003.08.086

23. R Development Core Team. R: A Language and Environment for Statistical Computing. Vienna, Austria; 2020. Available: https://www.r-project.org/

24. Magez S, Stijlemans B, Caljon G, Eugster HP, De Baetselier P. Control of experimental Trypanosoma brucei infections occurs independently of lymphotoxin- $\alpha$ induction. Infect Immun. 2002;70: 1342-1351. doi:10.1128/IAI.70.3.1342-1351.2002

25. Ndungu K, Thungu D, Wamwiri F, Mireji P, Ngae G, Gitonga P, et al. Route of inoculation influences Trypanosoma congolense and Trypanosoma brucei brucei virulence in Swiss white mice. PLoS One. 2019;14. doi:10.1371/journal.pone.0218441

26. Frank SA. A multistage theory of age-specific acceleration in human mortality. BMC Biol. 2004;2: 16. doi:10.1186/1741-7007-2-16

27. Frank SA. Age-Specific Acceleration of Cancer. Curr Biol. 2004;14: 242-246.

doi:10.1016/j.cub.2003.12.026 
medRxiv preprint doi: https://doi.org/10.1101/2020.06.20.20134205; this version posted June 22, 2020. The copyright holder for this preprint (which was not certified by peer review) is the author/funder, who has granted medRxiv a license to display the preprint in perpetuity.

It is made available under a CC-BY 4.0 International license.

28. Pletzer D, Mansour SC, Wuerth K, Rahanjam N, Hancock REW. New mouse model for chronic infections by gram-negative bacteria enabling the study of anti-infective efficacy and host-microbe interactions.

MBio. 2017;8. doi:10.1128/mBio.00140-17

29. Kamada N, Kim YG, Sham HP, Vallance BA, Puente JL, Martens EC, et al. Regulated virulence controls the ability of a pathogen to compete with the gut microbiota. Science (80- ). 2012;336: 1325-1329.

doi:10.1126/science.1222195

30. Gavrilov LA, Gavrilova NS. New Trend in Old-Age Mortality: Gompertzialization of Mortality Trajectory. Gerontology. 2019;65: 451-457. doi:10.1159/000500141

31. Cole JJ, Robertson NA, Rather MI, Thomson JP, McBryan T, Sproul D, et al. Diverse interventions that extend mouse lifespan suppress shared age-associated epigenetic changes at critical gene regulatory regions. Genome Biol. 2017;18: 58. doi:10.1186/s13059-017-1185-3

32. Darby C. Interactions with microbial pathogens. WormBook : the online review of C. elegans biology. 2005. pp. 1-15. doi:10.1895/wormbook.1.21.1

33. Bhinder G, Sham HP, Chan JM, Morampudi V, Jacobson K, Vallance BA. The Citrobacter rodentium mouse model: studying pathogen and host contributions to infectious colitis. J Vis Exp. 2013; e50222. doi:10.3791/50222

34. Ren C, Webster P, Finkel SE, Tower J. Increased Internal and External Bacterial Load during Drosophila Aging without Life-Span Trade-Off. Cell Metab. 2007;6: 144-152. doi:10.1016/j.cmet.2007.06.006

35. Gonçalves MC, Horewicz VV, Lückemeyer DD, Prudente AS, Assreuy J. Experimental Sepsis Severity Score Associated to Mortality and Bacterial Spreading is Related to Bacterial Load and Inflammatory Profile of Different Tissues. Inflammation. 2017;40: 1553-1565. doi:10.1007/s10753-017-0596-3

36. Ahmed N, Heitlinger E, Affinass N, Kühl AA, Xenophontos N, Jarquin VH, et al. A Novel Non-invasive 
medRxiv preprint doi: https://doi.org/10.1101/2020.06.20.20134205; this version posted June 22, 2020. The copyright holder for this preprint (which was not certified by peer review) is the author/funder, who has granted medRxiv a license to display the preprint in perpetuity.

It is made available under a CC-BY 4.0 International license .

Method to Detect RELM Beta Transcript in Gut Barrier Related Changes During a Gastrointestinal

Nematode Infection. Front Immunol. 2019;10: 445. doi:10.3389/fimmu.2019.00445

37. Ohlsen K, Hertlein T. Towards clinical application of non-invasive imaging to detect bacterial infections.

Virulence. Taylor and Francis Inc.; 2018. pp. 943-945. doi:10.1080/21505594.2018.1425072

38. Leevy WM, Serazin N, Smith BD. Optical imaging of bacterial infection models. Drug Discovery Today:

Disease Models. NIH Public Access; 2007. pp. 91-97. doi:10.1016/j.ddmod.2007.07.001

39. Vega NM, Gore J. Stochastic assembly produces heterogeneous communities in the Caenorhabditis elegans intestine. PLoS Biol. 2017;15. doi:10.1371/journal.pbio.2000633

40. White AG, Fu N, Leevy WM, Lee JJ, Blasco MA, Smith BD. Optical imaging of bacterial infection in living mice using deep-red fluorescent squaraine rotaxane probes. Bioconjug Chem. 2010;21: 1297-1304. doi:10.1021/bc1000998

41. Armah HB, Wilson NO, Sarfo BY, Powell MD, Bond VC, Anderson W, et al. Cerebrospinal fluid and serum biomarkers of cerebral malaria mortality in Ghanaian children. Malar J. 2007;6: 147. doi:10.1186/14752875-6-147

42. Buppan P, Putaporntip C, Pattanawong U, Seethamchai S, Jongwutiwes S. Comparative detection of plasmodium vivax and plasmodium falciparum DNA in saliva and urine samples from symptomatic malaria patients in a low endemic area. Malar J. 2010;9: 1-7. doi:10.1186/1475-2875-9-72

43. Fink MP. Animal models of sepsis. Virulence. Taylor and Francis Inc.; 2014. pp. 143-153. doi:10.4161/viru.26083

44. Lewis AJ, Seymour CW, Rosengart MR. Current Murine Models of Sepsis. Surg Infect (Larchmt). 2016;17: 385-393. doi:10.1089/sur.2016.021

45. Aaberge IS, Eng J, Lermark G, Løvik M. Virulence of Streptococcus pneumoniae in mice: A standardized 
medRxiv preprint doi: https://doi.org/10.1101/2020.06.20.20134205; this version posted June 22, 2020. The copyright holder for this preprint (which was not certified by peer review) is the author/funder, who has granted medRxiv a license to display the preprint in perpetuity.

It is made available under a CC-BY 4.0 International license .

method for preparation and frozen storage of the experimental bacterial inoculum. Microb Pathog.

1995;18: 141-152. doi:10.1016/S0882-4010(95)90125-6

46. Barnes PD, Bergman MA, Mecsas J, Isberg RR. Yersinia pseudotuberculosis disseminates directly from a replicating bacterial pool in the intestine. J Exp Med. 2006;203: 1591-1601. doi:10.1084/jem.20060905

47. Borges DC, Araújo NM, Cardoso CR, Lazo Chica JE. Different parasite inocula determine the modulation of the immune response and outcome of experimental Trypanosoma cruzi infection. Immunology.

2013;138: 145-156. doi:10.1111/imm.12022

48. Keeling MJ, Rohani P. Modeling Infectious Diseases in Humans and Animals. Princeton University Press; 2008. doi:10.2307/j.ctvcm4gk0

49. Grenfell B, Harwood J. (Meta) population dynamics of infectious diseases. Trends in Ecology and Evolution. Elsevier Ltd; 1997. pp. 395-399. doi:10.1016/S0169-5347(97)01174-9

50. Grant AJ, Restif O, McKinley TJ, Sheppard M, Maskell DJ, Mastroeni P. Modelling within-Host Spatiotemporal Dynamics of Invasive Bacterial Disease. Relman DA, editor. PLoS Biol. 2008;6: e74. doi:10.1371/journal.pbio.0060074

51. Antia R, Levin BR, May RM. Within-host population dynamics and the evolution and maintenance of microparasite virulence. Am Nat. 1994;144: 457-472. doi:10.1086/285686

52. Gilchrist MA, Sasaki A. Modeling host-parasite coevolution: A nested approach based on mechanistic models. J Theor Biol. 2002;218: 289-308. doi:10.1006/jtbi.2002.3076 